\title{
PENERAPAN ACTIVE LEARNING UNTUK MENINGKATKAN KEMANDIRIAN BELAJAR SISWA DAN HASIL BELAJAR IPS PADA SISWA KELAS 5 SD
}

\author{
Vera Risti Monika ${ }^{1}$, Firosalia Kristin ${ }^{2}$, Indri Anugraheni ${ }^{3}$ \\ ${ }^{1}$ Program Studi Pendidikan Guru Sekolah Dasar, Universitas Kristen satya Wacana Salatiga, 292013144@student.uksw.edu \\ ${ }^{2}$ Program Studi Pendidikan Guru Sekolah Dasar, Universitas Kristen satya Wacana Salatiga, firosalia.kristin@staff.uksw.edu \\ ${ }^{3}$ Program Studi Pendidikan Guru Sekolah Dasar, Universitas Kristen satya Wacana Salatiga, indri.anugraheni@staff.uksw.edu
}

INFO ARTIKEL
Riwayat Artikel:
Diterima : $13-04-2018$
Disetujui : 21-04-2018

Kata Kunci:

KemandirianBelajar

Hasil Belajar

Active Learning

Card Sort

\begin{abstract}
ABSTRAK
Abstrak: Mengetahui langkah-langkah penerapan Active Learning tipe Card Sort, meningkatkan kemandirian dan hasil belajar IPS melalui Active Learning tipe Card Sort di kelas 5 SD Negeri Lopait 01 adalah tujuan penelitian ini. Penelitian ini berjenis Penelitian Tindakan Kelas. Teknik analisis data menggunakan tes dan non tes. Hasil penelitian hasil belajar pra siklus $(40,74 \%)$ siklus I meningkat $(74,07 \%)$ meningkat lagi siklus II (92,59\%). Hasil penelitian kemandirian belajar, pra siklus $(68,8 \%)$ siklus I meningkat $(76,94 \%)$ meningkat lagi siklus II, (81,67\%). Dengan demikian penerapan Active Learning tipe Card Sort dapat meningkatkan kemandirian belajar dan hasil belajar IPS siswa kelas 5 SD Negeri Lopait 01.
\end{abstract}

\begin{abstract}
Knowing the steps of implementing Active Learning Card Sort type, increasing the independence and learning outcomes of IPS through Active Learning Card Sort type in 5th grade State Elementary School Lopait 01 is the purpose of this research. This research is a Class Action Research type. Data analysis techniques using test and non test. Result of research result of pre cycle study (40,74\%) cycle I increase (74,07\%) increase again cycle II (92,59\%). Result of research self-reliance learning, pre cycle (68,8\%) cycle I increase (76,94\%) increase again cycle II, (81,67\%). Thus the implementation of Active Learning Card Sort type can improve the independence of learning and learning outcomes IPS 5th grader Elementary School Elementary School Lopait 01.
\end{abstract}

\section{A. LATAR BELAKANG}

Umumnya proses pembelajaran yang terjadi selama ini bersifat satu arah, dimana guru menyampaikan materi kepada siswa, setelah menganggap siswa mengerti materi tersebut, guru menyuruh siswa untuk mencatat materi tersebut pada buku mereka. Proses pembelajaran seperti ini menyebabkan siswa kurang memperlihatkan materi yang diajarkan oleh guru. Kondisi ini dikarenakan dalam proses pembelajaran guru langsung memberikan contoh dan menjelaskannya, setelah menganggap siswa sudah mengerti, guru kemudian memberikan soal kepada siswa untuk dikerjakan. Menurut Kristin, F (2017:406) proses pembelajaran yang satu arah dirubah menjadi dua arah atau banyak arah sehingga siswa dapat terlihat secara langsung. Dalam pembelajaran yang dilakukan akan lebih bermakna jika semua terlibat. Hal yang terpenting dalam kegiatan pembelajaran adalah terjadinya proses belajar (learning process). Khususnya mata pelajaran IPS di SD jika proses pembelajarannya hanya satu arah yaitu terpusat pada guru siswa cenderung tidak mandiri dalam belajar. Dimasa yang akan datang peserta didik akan menghadapi tantangan berat karena kehidupan masyarakat global selalu mengalami perubahan setiap saat. Oleh karena itu mata pelajaran IPS dirancang untuk mengembangkan pengetahuan, pemahaman, dan kemampuan analisis terhadap kondisi sosial masyarakat dalam memasuki kehidupan bermasyarakat yang dinamis. Kondisi ini menuntut pembelajaran yang berpusat pada peserta didik. Dalam memenuhi hasil belajar yang baik salah satu faktor yang mendukung adalah kemandirian dalam belajar.

Suatu kekuatan internal individu yang diperoleh melalui proses individuasi, yaitu proses realisasi kedirian dan proses menuju kesempurnaan yang disebut kemandirian. Diri yaitu inti dari kepribadian dan merupakan titik pusat yang menyelaraskan dan mengoordinasikan seluruh aspek kepribadian (Ali, 2006:114). Sumarmo (2010:88) menyatakan individu yang memiliki kemandirian belajar yang tinggi cenderung belajar lebih aktif, mampu memantau, mengevaluasi, dan mengatur belajar lebih efektif yaitu menghemat waktu dalam menyeleseikan tugasnya, mengatur waktu belajar secara efisien. Jadi, kemandirian belajar merupakan hal penting yang perlu ditingkatkan guna mendukung keberhasilan belajar siswa. Peserta didik dihadapkan pada permasalahanpermasalahan hidup yang riil untuk dipecahkannya. 
Pembelajaran ini menjadi suatu kebiasaan, sehingga peserta didik kreatif dan berkembang potensinya untuk menganalisis temuan-temuan yang ada di lapangan. Dalam belajarpun diperlukan kemandirian diri sendiri guna menunjang keinginan untuk mengetauhi hal baru. Hal ini dapat menjadi salah satu faktor keberhasilan dalam belajar, apabila tidak ada kemandirian didalam diri sendiri, belajar akan terasa tidak bersemangat dan menjadikan belajar kurang efektif. Hasil belajar yang baik akan diperoleh apabila kita sungguh-sungguh dalam melaksanakan kegiatan belajar tersebut. Satu faktor penting dalam meraih belajar yang efektif karena tidak selamanya belajar bergantung kepada orang lain yaitu dengan belajar mandiri.

Dari wawancara dengan guru kelas 5 SD Negeri Lopait 01, rata-rata hasil belajar IPS pada UTS berada dibawah KKM (Kriteria Ketuntasan Minimal) yang seharusnya mencapai nilai 66, siswa yang tidak memenuhi KKM atau tidak tuntas sebesar 16 dari 27 siswa $(59,26 \%)$ dan hanya 11 siswa saja $(40,74 \%)$ yang tuntas. Setelah di observasi lebih lanjut ternyata rendahnya hasil belajar siswa kelas 5 SD Negeri Lopait o1 dikarenakan guru belum mencoba menerapkan model pembelajaran yang lain. Dalam pembelajaran guru cenderung menggunakan model pembelajaran konvensional seperti ceramah. Model pembelajaran ini kurang efektif, membuat siswa bosan dan kemandirian dalam belajarnya pun kurang. Siswa cenderung lebih mementingkan diri sendiri. Model pembelajaran yang dilakukan oleh guru kurang memberi kesempatan dan latihan kepada siswa yang ingin mengungkapkan gagasan yang dimiliknya, sehingga siswa yang memiliki gagasan memilih untuk diam dan mengikuti semua perintah dari guru tanpa ada rasa ingin tahu yang timbul dalam diri sendiri. Interaksi antar siswa dan interaksi siswa dan guru juga kurang terlihat. Kesempatan siswa untuk bertanya atau mengemukakan gagasan masih kurang. Ketika proses pembelajaran siswa kurang mandiri dalam belajar dikarenakan mereka akan belajar ketika disuruh oleh guru. Sejalan dengan apa yang dikemukakan Kristin, F., \& Rahayu, D (2016:84-85) yaitu kurang efektifnya proses pembelajaran dapat berasal dari siswa, guru maupun sarana dan prasarana yang ada, minat dan motivasi siswa yang rendah, kinerja guru yang rendah, serta kurang memadainya sarana dan prasarana berdampak pembelajaran menjadi kurang efektif. Pembelajaran Hal ini berdampak buruk kepada hasil belajar mereka. Siswa berkemampuan tinggi boleh saja di abaikan karena mereka sadar bahwa belajar sebagai kebutuhan mereka, lalu bagaimana dengan siswa yang berkemampuan rendah mereka tentu saja berpaku pada guru dalam hal belajar. Mengacu dari tujuan pendidikan yang disampaikan oleh Anugraheni, I (2018:33) bahwa pendidikan bertujuan untuk menguasai pengetahuan, pengembangan kepribadian, kemampuan sosial, ataupun kemampuan dalam bekerja. Sejatinya guru harus membimbing siswa-siswanya untuk melangkah ke tingkat yang lebih tinggi guna peningkatan kemampuan belajarnya disekolah demi kemajuan siswa tersebut. Membimbing ialah usaha yang dilakukan guru untuk mengantarkan siswa kearah kedewasaan baik secara jasmani dan rohani dan guru juga diharapkan mampu mengarahkan, melatih serta mengevaluasi siswa (Anugraheni, I, 2017:206).

Model pembelajaran yang tepat sangat membantu guru dalam mencapai tujuan pendidikan yang hendak dicapai. Model pembelajaran Active Learning tipe Card Sort dapat menjadi solusi untuk mengatasi rendahnya kemandirian belajar dan hasil belajar siswa kelas $5 \mathrm{SD}$ Negeri Lopait 01. Keberhasilan penggunaan model pembelajaran ini telah dibuktikan dengan penelitian yang dilakukan oleh Rahmaningrum, M (2016) tentang peningkatan hasil belajar IPS melalui strategi pembelajaran aktif Card Sort siswa kelas 5. hasil belajar mengalami peningkatan pada setiap siklusnya. Pada pra siklus nilai rata-rata 65,15 dengan ketuntasan belajar sebesar (19,35\%). Kemudian meningkat pada siklus I rata-rata 74 dengan ketuntasan belajar (54,83\%). Selanjutnya meningkat lagi di siklus ke II rata-rata 81,47 dengan ketuntasan belajar (87,09\%).

Berdasarkan latar belakang diatas, maka rumusan masalah dalam penelitian ini adalah apakah model pembelajaran Active Learning tipe Card Sort ini dapat meningkatkan kemandirian belajar siswa dan hasil belajar IPS siswa kelas 5 SD Negeri Lopait 01. Dari rumusan masalah tersebut dapat diketahui tujuan diadakannya penelitian ini adalah untuk mengetahui peningkatan kemandirian belajar siswa dan hasil belajar IPS siswa kelas 5 SD Negeri Lopait 01 melalui model pembelajaran Active Learning tipe Card Sort.

Mata pelajaran IPS dirancang untuk mengembangkan pengetahuan, pemahaman, dan kemampuan analisis terhadap kondisi sosial masyarakat dalam memasuki kehidupan bermasyarakat yang dinamis (Sapriya, 2012:194). Dengan demikian IPS merupakan bidang pengetahuan yang digali dari kehidupan praktis sehari-hari karena ilmu sejarah, geografi serta ekonomi adalah hal-hal yang ditemui dalam kehidupan sekitar kita dalam kelangsungan hidup bersama di dalam masyarakat. Masyarakat merupakan sumber serta objek kajian materi pendidikan IPS, yaitu berpijak pada kenyataan hidup yang riil (nyata). Lain halnya dengan apa yang di ungkapkan Kristin, F (2016:76) Ips adalah ilmu yang mempelajari berbagai disiplin ilmu yang terpadu berkaitan dengan manusia dan lingkungannya. Pendapat yang berbeda juga diungkapkan oleh Rahmaningrum, M (2016:914) bahwa keberadaan IPS sebagai mata pelajaran di sekolah sudah tidak terbantahkan kelahirannya karena adanya kebutuhan masyarakat maju yang beradap, adil, makmur, dan sejahtera.

IPS melihat bagaimana manusia hidup dengan sesamanya, dengan tetangganya dari lingkungan dekat sampai yang jauh. Bagaimana mereka melakukan 
aktivitas untuk memenuhi kebutuhan hidupnya. Dengan kata lain bahan kajian atau belajar IPS adalah manusia dengan lingkungannya (Hidayati, dkk, 2010:8). Berdasarkan beberapa pendapat diatas, dapat disimpulkan bahwa IPS merupakan salah satu mata pelajaran perpaduan dari mata pelajaran geografi, ilmu politik, ilmu hukum, ekonomi, sejarah, antropologi, psikologi, dan generalisasi yang mengkaji seperangkat peristiwa, fakta, konsep, dan generalisasi yang berkaitan dengan isu sosial yang terpadu berkaitan dengan manusia dan lingkungannya karena demi negara yang maju, beradap, adil, makmur, dan sejahtera. Pada jengjang sekolah dasar IPS merupakan perpaduan mata pelajaran sejarah, geografi, dan ekonomi.

Pemilihan model pembelajaran merupakan salah satu hal penting yang harus dipahami oleh setiap guru. Salah satunya pembelajaran yang dapat membuat siswa aktif denganmelibatkan siswa dalam belajar yaitu dengan model pembelajaran Active Learning (pembelajaran aktif) dimaksudkan untuk mengoptimalkan penggunaan semua potensi yang dimiliki dan agar siswa tetap tertuju pada proses pembelajaran yang berlangsung. Sama halnya dengan apa yang di kemukakan oleh Baharun, H (2015:37) bahwa pendekatan Active Learning merupakan strategi belajar mengajar yang bertujuan untuk meningkatkan mutu pendidikan dan untuk mencapai keterlibatan siswa agar efektif dan efisien dalam belajar membutuhkan berbagai pendukung dalam proses belajar dan dari sarana belajar. Menciptakan pembelajaran aktif Warsono dan Hariyanto (2013:12) menjelaskan bahwa pembelajaran aktif mengkondisikan agar siswa selalu melakukan pengalaman belajar yang bermakna dan senantiasa berpikir tentang apa yang dilakukannya selama pembelajaran. Cara terbaik untuk meningkatkan pembelajaran aktif Silberman (2013:124) mengungkapkan bahwa dengan cara memberikan tugas kepada siswa untuk dikerjakan dalam kelompok kecil sehingga mendapatkan dukungan dari sesama siswa, perbedaan sudut pandang, pengetahuan, dan keterampilan menjadikan pembelajaran kolaboratif bagian yang berharga dalam suasana pembelajaran di kelas.

Salah satu metode dalam pembelajaran aktif adalah metode pembelajaran card sort (sortir kartu) yang merupakan pembelajaran yang menekankan keaktifan siswa dan akhirnya anak akan tergerak kemandiriannya dalam belajar. Silberman (2013:171) menjelaskan bahwa card sort (memilah dan memilih kartu) adalah kegiatan kolaboratif yang bisa digunakan untuk mengajarkan konsep, penggolongan sifat, fakta tentang suatu objek atau mengulangi informasi. Metode pembelajaran tersebut juga dapat melakukan aktivitas belajar secara individu maupun kelompok, seperti yang dijelaskan Warsono dan Hariyanto (2013:47) card sort merupakan gabungan antara pembelajaran aktif individual dengan pembelajaran kolaboratif atau pembelajaran kooperatif bergantung pada keinginan guru. Sejalan dengan pendapat yang telah dikemukakan diatas, Rahmaningrum, M (2016:917) menjelaskan salah satu pembelajaran aktif yang dapat diterapkan sesuai dengan karakteristil siswa sekolah dasar adalah Card Sort. Strategi ini merupakan aktivitas kerjasama yang bisa digunkana untuk mengajarkan konsep, karakteristik klasifikasi, fakta tentang benda, atau menilai informasi, selain itu gerak fisik yang ada didalamnya dapat membantu menggairahkan siswa yang merasa penat dan bosan.

Warsono dan Hariyanto (2013:47-48) menjelaskan contoh penggunaan pembelajaran aktif tipe Card Sort dalam pembelajaran IPS untuk SD sebagai berikut: (1)Bagikan kartu indeks kepada siswa yang meliputi lebih dari satu macam kategori terkait mata pelajaran IPS. (2)Setelah mendapat kartu, setiap siswa bergerak keliling kelas dan menemukan kartu dengan kategori sama. jika waktunya cukup biarkan siswa menemukan kategorinya sendiri, tetapi jika waktunya tidak leluasa sebaiknya guru umumkan kepada seluruh kelas kategori apa saja yang tersedia. (3)Siswa yang memiliki kartu indeks dengan kategori yang sama berkumpul. (4)Para siswa dalam kategori yang sama bermusyawarah untuk menunjukkan salah satu orang untuk mewakili kelompok melakukan presentasi di depan kelas. Siswa yang lain dalam kelompok lain boleh menanggapi. (5) Guru melakukan refleksi dengan mengungkap butirbutir penting dari setiap kategori bahan ajar.

Kemandirian dalam belajar dapat bekembang dengan baik apabila diberikan kesempatan untuk memilih apa yang akan dipelajarinya namun masih sesuai dengan konteks materi yang seharusnya ia belajar. Menurut Desminta (2012:190), pendidikan di sekolah perlu melakukan upaya-upaya pengembangan kemandirian peserta didik diantaranya adalah 1) Mengembangkan proses belajar mengajar yang demokratis, yang memungkinkan anak merasa dihargai; 2) Mendorong anak untuk berpartisipasi aktif dalam pengambilan keputusan dan dalam berbagai kegiatan sekolah; 3) Memberi kebebasan kepada anak untuk mengeksplorasi lingkungan, mendorong rasa ingin tahuu mereka; 4) Penerimaan positif tanpa syarat kelebihan dan kekurangan anak, tidak membedabedakan anak yang satu dengan yang lain; dan 5) Menjalin hubungan yang harmonis dan akrab dengan anak. Sundayana, R (2016:34) berpendapat mengenai kemandirian belajar adalah suatu proses belajar dimana setiap individu dapat mengambil inisiatif, dengan atau tanpa bantuan orang lain, dalam hal menentukan kegiatan belajarnya seperti merumuskan tujuan belajar, sebagai sumber belajar (baik berupa orang ataupun bahan), mendiagnosa kebutuhan belajar dan mengontrol sendiri proses pembelajarannya.

Haris mudjiman (2011:10) menyebutkan ada lima tahap penahapan dalam belajar mandiri yaitu 1) Tahap masuknya ransangan yang menarik perhatian 
pembelajar; 2) Tahap tumbuhnya niat untuk merespon rangsangan; 3) Tahap pembuatan keputusan atau tahap penumbuhan motivasi; 4) tahap pelaksanaan tindakan belajar; dan 5) tahap evaluasi.guru berperan penting dalam memfasilitasi siswanya untuk melewati tahapantahapan tersebut. Rangsangan untuk menumbuhkan kemauan belajar dapat dilakukan dengan menciptakan kegiatan belajar aktif yang melibatkan siswa. Model pembelajaran juga sangat berperan penuh terhadap berhasilnya perkembangan kemandirian belajar siswa.

Model pembelajaran aktif misalnya, menurut Santosa, S. K. D. S (2013:91) model pembelajaran aktif dapat membangkitkan kemandirian siswa, siswa akan secara aktif menggunakan otak baik untuk menemukan ide pokok dari materi, memcahkan persoalan atau mengaplikasikan apa yang baru mereka pelajari ke dalam suatu persoalan yang ada dalam kehidupan nyata. Dari uraian diatas kemandirian belajar adalah rasa ketidaktergantungan pada orang lain dan disertai rasa berani mengambil keputusan dengan mempertimbangkan konsekuensi yang akan diperoleh. Ada 8 aspek untuk menentukankemandirian belajar yaitu tidak tergantung oranglain, percaya diri, mengkontrol diri, motivasi, tanggung jawab, inisiatif belajar, mencari dan memanfaatkan sumber yang relevan, evaluasi.

Belajar adalah suatu proses menuju kesuksessan tersembunyi dengan belajar dapat membuat yang tidak mungkin menjadi mungkin. Dalam tingkat sekolah, belajar diwajibkan guna memperoleh prestasi yang baik dan bekal hidup dikemudian hari. Menurut Slameto (2010:2), mendefinisikan belajar sebagai suatu proses usaha yang dilakukan seseorang untuk memperoleh suatu perubahan tingkah laku yang baru secara keseluruhan, sebagai hasil pengalamannya sendiri dalam interaksi dengan lingkungannya.

Menurut Abdurrahman dalam Jihad dan Haris (2013:14) hasil belajar merupakan kemampuan yang diperoleh anak setelah melalui kegiatan belajar. Selanjutnya Nawawi (Susanto, 2013:5) hasil belajar diartikan sebagai keberhasilan siswa dalam memahami pembelajaran di sekolah yang ditunjukkan dengan skor sesuai dengan hasil tes pada mata pelajaran tertentu. Sejalan dengan apa yang dikemukakan oleh Anugraheni, I (2017:249) bahwa penguasaan hasil belajar oleh seseorang dapat dilihat dari perilakunya, baik perilaku dalam bentuk penguasaan pengetahuan, keterampilan berfikir maupun ketrampilan motorik hal yang demikian merupakan hasil belajar yang kegiatan atau perilaku hampir sebagian besar diperlihatkan seseorang.

Berdasarkan uraian diatas dapat disimpulkan hasil belajar adalah pemberian skor terhadap kemampuan siswa diperoleh dari pengukuran tes dan non tes yang dijadikan acuan untuk mengetahui kemampuan di dalam diri siswa.

Mata pelajaran IPS dirancang untuk mengembangkan pengetahuan, pemahaman, dan kemampuan analisis terhadap kondisi sosial masyarakat dalam memasuki kehidupan bermasyarakat yang dinamis (Sapriya, 2012:194). Dengan demikian IPS merupakan bidang pengetahuan yang digali dari kehidupan praktis sehari-hari karena ilmu sejarah, geografi serta ekonomi adalah hal-hal yang ditemui dalam kehidupan sekitar kita dalam kelangsungan hidup bersama di dalam masyarakat. Masyarakat merupakan sumber serta objek kajian materi pendidikan IPS, yaitu berpijak pada kenyataan hidup yang riil (nyata). Lain halnya dengan apa yang di ungkapkan Kristin, F (2016:76) Ips adalah ilmu yang mempelajari berbagai disiplin ilmu yang terpadu berkaitan dengan manusia dan lingkungannya. Pendapat yang berbeda juga diungkapkan oleh Rahmaningrum, M (2016:914) bahwa keberadaan IPS sebagai mata pelajaran di sekolah sudah tidak terbantahkan kelahirannya karena adanya kebutuhan masyarakat maju yang beradap, adil, makmur, dan sejahtera.

IPS melihat bagaimana manusia hidup dengan sesamanya, dengan tetangganya dari lingkungan dekat sampai yang jauh. Bagaimana mereka melakukan aktivitas untuk memenuhi kebutuhan hidupnya. Dengan kata lain bahan kajian atau belajar IPS adalah manusia dengan lingkungannya (Hidayati, dkk, 2010:8). Berdasarkan beberapa pendapat diatas, dapat disimpulkan bahwa IPS merupakan salah satu mata pelajaran perpaduan dari mata pelajaran geografi, ilmu politik, ilmu hukum, ekonomi, sejarah, antropologi, psikologi, dan generalisasi yang mengkaji seperangkat peristiwa, fakta, konsep, dan generalisasi yang berkaitan dengan isu sosial yang terpadu berkaitan dengan manusia dan lingkungannya karena demi negara yang maju, beradap, adil, makmur, dan sejahtera. Pada jengjang sekolah dasar IPS merupakan perpaduan mata pelajaran sejarah, geografi, dan ekonomi.

Pemilihan model pembelajaran merupakan salah satu hal penting yang harus dipahami oleh setiap guru. Salah satunya pembelajaran yang dapat membuat siswa aktif denganmelibatkan siswa dalam belajar yaitu dengan model pembelajaran Active Learning (pembelajaran aktif) dimaksudkan untuk mengoptimalkan penggunaan semua potensi yang dimiliki dan agar siswa tetap tertuju pada proses pembelajaran yang berlangsung. Sama halnya dengan apa yang di kemukakan oleh Baharun, H (2015:37) bahwa pendekatan Active Learning merupakan strategi belajar mengajar yang bertujuan untuk meningkatkan mutu pendidikan dan untuk mencapai keterlibatan siswa agar efektif dan efisien dalam belajar membutuhkan berbagai pendukung dalam proses belajar dan dari sarana belajar. Menciptakan pembelajaran aktif Warsono dan Hariyanto (2013:12) menjelaskan bahwa pembelajaran aktif mengkondisikan agar siswa selalu melakukan pengalaman belajar yang bermakna dan senantiasa berpikir tentang apa yang dilakukannya selama pembelajaran. Cara terbaik untuk meningkatkan 
pembelajaran aktif Silberman (2013:124) mengungkapkan bahwa dengan cara memberikan tugas kepada siswa untuk dikerjakan dalam kelompok kecil sehingga mendapatkan dukungan dari sesama siswa, perbedaan sudut pandang, pengetahuan, dan keterampilan menjadikan pembelajaran kolaboratif bagian yang berharga dalam suasana pembelajaran di kelas.

Salah satu metode dalam pembelajaran aktif adalah metode pembelajaran card sort (sortir kartu) yang merupakan pembelajaran yang menekankan keaktifan siswa dan akhirnya anak akan tergerak kemandiriannya dalam belajar. Silberman (2013:171) menjelaskan bahwa card sort (memilah dan memilih kartu) adalah kegiatan kolaboratif yang bisa digunakan untuk mengajarkan konsep, penggolongan sifat, fakta tentang suatu objek atau mengulangi informasi. Metode pembelajaran tersebut juga dapat melakukan aktivitas belajar secara individu maupun kelompok, seperti yang dijelaskan Warsono dan Hariyanto (2013:47) card sort merupakan gabungan antara pembelajaran aktif individual dengan pembelajaran kolaboratif atau pembelajaran kooperatif bergantung pada keinginan guru. Sejalan dengan pendapat yang telah dikemukakan diatas, Rahmaningrum, M (2016:917) menjelaskan salah satu pembelajaran aktif yang dapat diterapkan sesuai dengan karakteristil siswa sekolah dasar adalah Card Sort. Strategi ini merupakan aktivitas kerjasama yang bisa digunkana untuk mengajarkan konsep, karakteristik klasifikasi, fakta tentang benda, atau menilai informasi, selain itu gerak fisik yang ada didalamnya dapat membantu menggairahkan siswa yang merasa penat dan bosan.

Warsono dan Hariyanto (2013:47-48) menjelaskan contoh penggunaan pembelajaran aktif tipe Card Sort dalam pembelajaran IPS untuk SD sebagai berikut: (1)Bagikan kartu indeks kepada siswa yang meliputi lebih dari satu macam kategori terkait mata pelajaran IPS. (2)Setelah mendapat kartu, setiap siswa bergerak keliling kelas dan menemukan kartu dengan kategori sama. jika waktunya cukup biarkan siswa menemukan kategorinya sendiri, tetapi jika waktunya tidak leluasa sebaiknya guru umumkan kepada seluruh kelas kategori apa saja yang tersedia. (3)Siswa yang memiliki kartu indeks dengan kategori yang sama berkumpul. (4)Para siswa dalam kategori yang sama bermusyawarah untuk menunjukkan salah satu orang untuk mewakili kelompok melakukan presentasi di depan kelas. Siswa yang lain dalam kelompok lain boleh menanggapi. (5) Guru melakukan refleksi dengan mengungkap butirbutir penting dari setiap kategori bahan ajar.

Kemandirian dalam belajar dapat bekembang dengan baik apabila diberikan kesempatan untuk memilih apa yang akan dipelajarinya namun masih sesuai dengan konteks materi yang seharusnya ia belajar. Menurut Desminta (2012:190), pendidikan di sekolah perlu melakukan upaya-upaya pengembangan kemandirian peserta didik diantaranya adalah 1) Mengembangkan proses belajar mengajar yang demokratis, yang memungkinkan anak merasa dihargai; 2) Mendorong anak untuk berpartisipasi aktif dalam pengambilan keputusan dan dalam berbagai kegiatan sekolah; 3) Memberi kebebasan kepada anak untuk mengeksplorasi lingkungan, mendorong rasa ingin tahuu mereka; 4) Penerimaan positif tanpa syarat kelebihan dan kekurangan anak, tidak membedabedakan anak yang satu dengan yang lain; dan 5) Menjalin hubungan yang harmonis dan akrab dengan anak. Sundayana, R (2016:34) berpendapat mengenai kemandirian belajar adalah suatu proses belajar dimana setiap individu dapat mengambil inisiatif, dengan atau tanpa bantuan orang lain, dalam hal menentukan kegiatan belajarnya seperti merumuskan tujuan belajar, sebagai sumber belajar (baik berupa orang ataupun bahan), mendiagnosa kebutuhan belajar dan mengontrol sendiri proses pembelajarannya.

Haris mudjiman (2011:10) menyebutkan ada lima tahap penahapan dalam belajar mandiri yaitu 1) Tahap masuknya ransangan yang menarik perhatian pembelajar; 2) Tahap tumbuhnya niat untuk merespon rangsangan; 3) Tahap pembuatan keputusan atau tahap penumbuhan motivasi; 4) tahap pelaksanaan tindakan belajar; dan 5) tahap evaluasi.guru berperan penting dalam memfasilitasi siswanya untuk melewati tahapantahapan tersebut. Rangsangan untuk menumbuhkan kemauan belajar dapat dilakukan dengan menciptakan kegiatan belajar aktif yang melibatkan siswa. Model pembelajaran juga sangat berperan penuh terhadap berhasilnya perkembangan kemandirian belajar siswa.

Model pembelajaran aktif misalnya, menurut Santosa, S. K. D. S (2013:91) model pembelajaran aktif dapat membangkitkan kemandirian siswa, siswa akan secara aktif menggunakan otak baik untuk menemukan ide pokok dari materi, memcahkan persoalan atau mengaplikasikan apa yang baru mereka pelajari ke dalam suatu persoalan yang ada dalam kehidupan nyata. Dari uraian diatas kemandirian belajar adalah rasa ketidaktergantungan pada orang lain dan disertai rasa berani mengambil keputusan dengan mempertimbangkan konsekuensi yang akan diperoleh. Ada 8 aspek untuk menentukankemandirian belajar yaitu tidak tergantung oranglain, percaya diri, mengkontrol diri, motivasi, tanggung jawab, inisiatif belajar, mencari dan memanfaatkan sumber yang relevan, evaluasi.

Belajar adalah suatu proses menuju kesuksessan tersembunyi dengan belajar dapat membuat yang tidak mungkin menjadi mungkin. Dalam tingkat sekolah, belajar diwajibkan guna memperoleh prestasi yang baik dan bekal hidup dikemudian hari. Menurut Slameto (2010:2), mendefinisikan belajar sebagai suatu proses usaha yang dilakukan seseorang untuk memperoleh suatu perubahan tingkah laku yang baru secara 
keseluruhan, sebagai hasil pengalamannya sendiri dalam interaksi dengan lingkungannya.

Menurut Abdurrahman dalam Jihad dan Haris (2013:14) hasil belajar merupakan kemampuan yang diperoleh anak setelah melalui kegiatan belajar. Selanjutnya Nawawi (Susanto, 2013:5) hasil belajar diartikan sebagai keberhasilan siswa dalam memahami pembelajaran di sekolah yang ditunjukkan dengan skor sesuai dengan hasil tes pada mata pelajaran tertentu. Sejalan dengan apa yang dikemukakan oleh Anugraheni, I (2017:249) bahwa penguasaan hasil belajar oleh seseorang dapat dilihat dari perilakunya, baik perilaku dalam bentuk penguasaan pengetahuan, keterampilan berfikir maupun ketrampilan motorik hal yang demikian merupakan hasil belajar yang kegiatan atau perilaku hampir sebagian besar diperlihatkan seseorang.

Berdasarkan uraian diatas dapat disimpulkan hasil belajar adalah pemberian skor terhadap kemampuan siswa diperoleh dari pengukuran tes dan non tes yang dijadikan acuan untuk mengetahui kemampuan di dalam diri siswa.

\section{B. METODE PENELITIAN}

Jenis penelitian ini merupakan Penelitian Tindakan Kelas (PTK). Teknik pengumpulan data pada penelitian ini yaitu dengan teknik tes dan teknik non tes. Teknik tes yaitu serentetan pertanyaan latihan yang dipergunakan untuk mengukur ketrampilan, pengetahuan intelegensi, dan kemampuan atau bakat yang dimiliki oleh individu atau kelompok (Suharsimi Arikunto, 2006:150). Teknik non tes terdapat 3 bahasan yaitu observasi, dokumentasi, dan angket. Observasi atau pengamatan yaitu aktivitas pencatatan fenomena yang dilakukan secara sistematis (Slameto, 2015:232). Dokumentasi menurut Sugiono (2013:240) merupakan catatan peristiwa yang sudah berlalu. Dokumentasi bisa berbentuk gambar, tulisan, atau karya-karya monumental dari seseorang. Angket untuk mengukur tingkat kemandirian belajar siswa. Dalam penelitian ini peneliti menggunakan penilaian skala likert untuk mengukur kemandirian siswa. Teknik analisis data pada penelitian ini adalah teknik analisis data deskriptif kuantitatif. Data yang telah diperoleh dan diolah selanjutnya disimpulkan bagaimana hasil belajar dan kemandirian belajar siswa.

\section{HASIL DAN PEMBAHASAN}

\section{Hasil Belajar}

Di bawah ini adalah tabel perbandingan nilai hasil belajar siswa yang di mulai pada pra siklus, siklus I dan siklus II.

TABEL 1

PERBANDINGAN NILAI HASIL BELAJAR IPS SISWA KELAS 5 SD NEGERI LOPAIT 01

\begin{tabular}{|l|c|c|c|}
\hline \multicolumn{1}{|c|}{ Kategori Nilai } & $\begin{array}{c}\text { Pra } \\
\text { Siklus }\end{array}$ & $\begin{array}{c}\text { Siklus } \\
\text { I }\end{array}$ & $\begin{array}{c}\text { Siklus } \\
\text { II }\end{array}$ \\
\hline Nilai Terendah & 46 & 48 & 62 \\
\hline Nilai Tertinggi & 88 & 84 & 88 \\
\hline
\end{tabular}

\begin{tabular}{|l|c|c|c|}
\hline \multicolumn{1}{|c|}{ Kategori Nilai } & $\begin{array}{c}\text { Pra } \\
\text { Siklus }\end{array}$ & $\begin{array}{c}\text { Siklus } \\
\text { I }\end{array}$ & $\begin{array}{c}\text { Siklus } \\
\text { II }\end{array}$ \\
\hline Nilai Rata-Rata & 62,44 & 68,59 & 75,96 \\
\hline Tuntas & $\mathbf{1 1}$ & $\mathbf{2 0}$ & $\mathbf{2 5}$ \\
\hline Tidak tuntas & 16 & 7 & $\mathbf{2}$ \\
\hline Presentase Tuntas & $40,74 \%$ & $74,07 \%$ & $92,59 \%$ \\
\hline $\begin{array}{l}\text { Presentase Tidak } \\
\text { Tuntas }\end{array}$ & $59,26 \%$ & $25,93 \%$ & $7,41 \%$ \\
\hline
\end{tabular}

Dari Tabel 1 mengenai perbandingan hasil belajar siswa kelas 5 SD Negeri Lopait o1 disetiap siklusnya mengalami peningkatan yang signifikan. Hasil belajar pra siklus 11 siswa tuntas (40,74\%) dan 16 siswa tidak tuntas $(59,26 \%)$ dengan nilai rata-rata 62,44 nilai terendah 46 dan tertinggi 88 pada siklus I meningkat menjadi 20 siswa tuntas $(74,07 \%)$ dan 7 siswa tidak tuntas $(25,93 \%)$ nilai terendah 48 dan tertinggi 84 lalu meningkat lagi pada siklus II menjadi 25 siswa tuntas $(92,59 \%)$ dan 2 siswa tidak tuntas $(7,41 \%)$ dengan nilai rata-rata 75,96 nilai terendah 62 dan tertinggi 88. Dari setiap siklusnya siswa mempunyai progres belajar yang cukup tinggi. Benar adanya seperti yang disampaikan oleh Kristin, F (2016:79) bahawa hasil belajar diperoleh seseorang dari aktivitas yang dilakukan dan mengakibatkan terjadinya perubahan tingkah laku. Dalam penelitian ini hasil belajar yang didapatkan telah mengalami perubahan tingkah laku dari setiap siklusnya yang berdampak untuk hasil belajar siswa.

\section{Kemandirian Belajar}

Di bawah ini adalah tabel perbandingan skor kemandirian siswa yang di mulai pada pra siklus, siklus I dan siklus II.

TABEL 2

PERBANDINGAN SKOR KEMANDIRIAN BELAJAR SISWA KELAS 5 SD NEGERI LOPAIT 01

\begin{tabular}{|l|c|c|c|}
\hline Kategori Skor & $\begin{array}{c}\text { Pra } \\
\text { Siklus }\end{array}$ & Siklus I & Siklus II \\
\hline Baik Sekali & $\mathbf{1}$ & 12 & 16 \\
\hline Baik & 23 & 13 & 10 \\
\hline Cukup & 3 & 2 & 1 \\
\hline Kurang & 0 & 0 & 0 \\
\hline Kurang Sekali & 0 & 0 & 0 \\
\hline Skor Terendah & 46 & 66 & 74 \\
\hline Skor Tertinggi & 88 & 108 & 107 \\
\hline Skor Rata-Rata & 81,8 & 92,3 & 98 \\
\hline Jumlah Skor & 2209 & 2493 & 2646 \\
\hline Presentase Skor & $68,8 \%$ & $76,94 \%$ & $81,67 \%$ \\
\hline
\end{tabular}

Dari Tabel 2 terlampir perbandingan skor kemandirian belajar siswa menunjukkan peningkatan yang signifikan. Hasil penelitian siswa menunjukkan kemandirian belajar siswa pra siklus, 3 siswa berkategori cukup, 23 siswa berkategori baik dan 1 siswa berkategori baik sekali. Presentase skor pada pra siklus sebesar $(68,8 \%)$ dengan skor rata-rata 81,8 yang memiliki skor terendah 46 dan skor tertinggi 88 pada siklus I meningkat menjadi 2 siswa berkategori cukup, 13 siswa 
berkategori baik dan 12 siswa berkategori baik sekali. Presentase skor pada siklus I ini sebesar (76,94\%) dengan skor rata-rata 92,3 yang memiliki skor terendah 66 dan skor tertinggi 108 kemudian meningkat lagi pada siklus II meningkat menjadi 1 siswa berstatus cukup, 10 siswa berstatus baik dan 16 siswa berstatus baik sekali. Besar presentase skor pada siklus II ini adalah $(81,67 \%)$ dengan skor rata-rata 98 yang memiliki skor terendah 74 dan skor tertinggi 107.

Penelitian ini menggunakan model pembelajaran Active Learning tipe Card Sort pada pertemuan 1 dan 2 disetiap siklusnya. Komponen pembelajaran Active Learning tipe Card Sort sudah dapat diterapkan pada saat penelitian berlangsung sesuai apa yang telah peneliti rencanakan pada RPP. Pada pertemuan 1 sampai 2 peneliti menerapkan langkah-langkah model pembelajaran Active Learning tipe Card Sort yaitu membimbing siswa menemukan kategori kartu yang sama dan selanjutnya didiskusikan dengan teman sekategori. Hasil dari diskusi tadi di presentasikan ke depan kelas sesuai dengan kategori yang mereka dapat. Penerapan langkah-langkah model pembelajaran Active Learning tipe Card Sort tersebut sudah dapat diterapkan disetiap pembelajaran.

Hasil belajar siswa yang diperoleh dari setiap evaluasi didapatkan rata-rata disetiap siklusnya mengalamai peningkatan yang signifikan. Mulai dari pra siklus 11 siswa tuntas (40,74\%) dan 16 siswa tidak tuntas $(59,26 \%)$ dengan nilai rata-rata 62,44 nilai terendah 46 dan tertinggi 88 pada siklus I meningkat menjadi 20 siswa tuntas $(74,07 \%)$ dan 7 siswa tidak tuntas $(25,93 \%)$ nilai terendah 48 dan tertinggi 84 lalu meningkat lagi pada siklus II menjadi 25 siswa tuntas (92,59\%) dan 2 siswa tidak tuntas $(7,41 \%)$ dengan nilai rata-rata 75,96 nilai terendah 62 dan tertinggi 88.

Selain itu, hasil penelitian ini telah melengkapi dan memperkuat penelitian terdahulu seperti yang dilakukan oleh Rahmaningrum, M (2016) bahwa pembelajaran aktif Card Sort dapat meningkatan hasil belajar IPS siswa kelas 5. Hasil penelitian siswa menunjukkan kemandirian belajar siswa pra siklus, 3 siswa dalam status cukup, 23 siswa berstatus baik dan 1 siswa berstatus baik sekali. Presentase skor pada pra siklus sebesar $(68,8 \%)$ dengan skor rata-rata 81,8 yang memiliki skor terendah 46 dan skor tertinggi 88. Tingkat kemandirian siswa masih dipredikat cukup dengan presentase $68,8 \%$. Setengah dari siswa kelas 5 belum menyadari pentingnya kemandirian belajar. Hal ini disebabkan oleh cara guru dalam mengajar masih menggunakan metode konvensional jadi siswa hanya terpaku pada penjelasan guru yang mengakibatkan siswa pasif dan kemandirian belajar sangat kurang sehingga mempengaruhi hasil belajar siswa rendah.

Melihat rendahnya hasil belajar dan kemandirian siswa dalam belajar maka perlu diberikan tindakan penelitian untuk mengatasi rendahnya hasil belajar dan kemandirian belajar siswa, peneliti menggunakan model pembelajaran Active Learning tipe Card Sort sebagai upaya untuk meningkatkan kemandirian belajar siswa dan hasil belajar mata pelajaran IPS melalui penelitian tindakan kelas yang di laksanakan sebanyak dua siklus yaitu siklus I dan siklus II.

Pada kondisi pra siklus (kondisi awal) sebelum diadakan penelitian tindakan kelas 5 SD Negeri Lopait o1 skor rata-sata 62,44 dan setelah diberi tindakan penelitian pada siklus I skor rata-rata menjadi 68,59 dengan skor tertinggi 84 dan skor terendah 48. Hasil ini sebenarnya sudah memenuhi KKM namun mengingat banyaknya siswa yang mendapat nilai skor dibawah KKM yaitu ada 7 siswa yang belum tuntas. Penerapan model pembelajaran Active Learning tipe card Sort untuk hasil belajar pada siklus I ini juga dipengaruhi oleh kerja siswa waktu proses pembelajaran berlangsung Ada yang sudah paham dengan apa yang dimaksudkan oleh guru namun ada juga yang harus beberapa kali bertanya kepada guru maksud dari tugas yang diberikan. Hal ini juga menjadi faktor hasil belajar siswa, karena secara tidak langsung siswa ini kalah dibandingkan dengan teman-temannya yang sudah mengerti maksud dari tugas tersebut. Siswa lain sudah berdiskusi tentang apa yang mereka dapat dan masih ada yang bingung mencari dimana posisi mereka. Selanjutnya mengenai kemandirian belajar siswa setelah diadakan siklus I presentase meningkat menjadi $76,79 \%$. Namun kendala di siklus I ini masih saja terjadi. Diantaranya siswa yang gaduh sendiri saat mencari kategori kartunya dan merasa malas memahami kategori yang mereka dapatkan. Sehingga perlu diadakannya pemberian tindakan pada siklus II yaitu dengan memberikan motivasi yang lebih besar lagi untuk memahami materi, menampilkan gambar-gambar yang bersangkutan dengan materi, mengontrol siswa yang sering membuat kegaduhan di kelas sehingga mengganggu siswa lainnya dalam pemahaman materi.

Setelah diadakannya siklus II hasil skor rata-rata menjadi 75,96 dengan skor tertinggi 88 dan skor terendah 62. Hasil dari siklus II ini sudah menunjukkan peningkatan yang signifikan dari pada siklus sebelumnya. Hasil dari siklus II ternyata telah mengalami peningkatan yaitu dengan presentase keberhasilan $81,67 \%$ ternyata kemandirian siswa dapat terwujud melalui model pembelajaran tersebut. Penerapan model pembelajaran Active Learning tipe card Sort untuk hasil belajar pada siklus II ini mengalami perubahan yang baik siswa dapat dikondisikan dengan baik untuk mengikuti pembelajaran kemandirian juga meningkat dengan pemberian tugas untuk menyortir kartu yang diberikan oleh guru. Hal ini membuktikan model pembelajaran Active Learning tipe Card Sort dapat meningkatkan kemandirian belajar siswa. Maka dari itu, pelaksanaan perbaikan siklus ini dapat diakhiri pada sikklus II.

Peningkatan hasil belajar ini karena dalam proses belajar siswa mencari materi sendiri dan berusaha 
memahaminya dengan presentasi didepan kelas secara tidak langsung siswa di tuntut untuk memahami materi yang dipelajari. Faktor pendukung juga melalui diskusi antar kelompok untuk mendiskusikan kategori yang mereka dapat sehingga ingatan siswa mengenai materi yang dipelajari dapat terserap ke dalam pikiran mereka melalui diskusi dan pemahaman materi. hal ini sejalan dengan apa yang dikemukakan Slameto (2010:2), yaitu belajar sebagai suatu proses usaha yang dilakukan seseorang untuk memperoleh suatu perubahan tingkah laku yang baru secara keseluruhan, sebagai hasil pengalamannya sendiri dalam interaksi dengan lingkungannya. Disini siswa mendapatkan perubahan tingkah laku dengan berani mendiskusikan sesuatu antar kelompok sehingga pengalaman mereka dalam belajar benar-benar terjadi tidak sekedar duduk diam menerima pembelajaran yang sedang disampaikan. Siswa juga memiliki motivasi untuk belajar, antusias dan aktif dalam pembelajaran, memiliki rasa percaya diri yang tinggi, bertanggung jawab atas tugas yang diberikan, pemanfaatan sumber belajar juga terlihat dalam proses pembelajaran. Hal ini dapat berdampak pada nilai pembelajaran siswa yang meningkat.

Dalam peneltian ini, proses pembelajaran pada siklus I dan siklus II sudah berjalan sesuai langkahlangkah model pembelajaran Active Learning tipe Card Sort.Langkah-langkah model pembelajaran Active Learning tipe Card Sort yang digunakan yaitu membagi potongan kertas berisi informasi, mencari kartu dengan kategori yang sama, musyawarah atau berdiskusi mengenai kategori yang telah ditentukan dalam masingmasing kelompok, mempresentasikan hasil diskusi, refleksi mengungkapkan poin-poin penting dari setiap kategori bahan ajar (Warsono dan Hariyanto, 2013:4748). Hasil penelitian ini sejalan dengan pendapat Santosa, S. K. D. S (2013:91) model pembelajaran aktif dapat membangkitkan kemandirian siswa, siswa akan secara aktif menggunakan otak baik untuk menemukan ide pokok dari materi, memecahkan persoalan atau mengaplikasikan apa yang baru mereka pelajari ke dalam suatu persoalan yang ada dalam kehidupan nyata. Sejalan dengan apa yang dikemukakan Kristin, F (2016:407) belajar aktif bukan hanya seperangkat kegiatan namun lebih kearah suatu sikap yang mesti diambil baik oleh peserta didik, guru maupun sekolah untuk menjadikan pembelajaran efektif.

Keunggulan penelitian ini dibandingkan dengan penelitian sebelumnya adalah penelitian ini menggunakan model pembelajaran Active Learning tipe Card Sort yang diterapkan dalam pembelajaran IPS kelas 5. Model pembelajaran tersebut diterapkan untuk mengetahui tingkat kemandirian siswa melalui penilaian menggunakan skala likert. Card Sort disini melatih kemandirian siswa melalui pemahaman yang harus siswa gali sendiri jika siswa hanya diam saja tanpa ada respon siswa tidak akan paham dengan kategori kartu yang mereka dapat, maka dari itu mereka harus secara mandiri mencari kategori yang mereka dapatkan.. Mengamati secara spesifik tingkat kemandirian belajar siswa melalui pemberian angket yang dapat terlihat dari minat siswa untuk belajar dapat diukur menggunakan angket tersebut. Selain itu penelitian ini juga menggunkana model pembelajaran yang dapat merangsang kreatifitas siwa dalam belajar untuk megungkapkan ide yang ada dalam diri siswa. Siswa dilatih tidak menjadi pendengar saja, tetapi juga melakukan pembelajaran secara langsung sehingga peluang siswa memahami pembelajaran sangat besar berhasilnya karena siswa secara langsung memahami apa yang mereka dapat dan dituangkan dalam diskusi bersama sehingga terjadi komunikasi antar siswa. Karena itulah siswa menjadi semakin percaya diri.

\section{SIMPULAN DAN SARAN}

Berdasarkan hasil penelitian dan pembahasan yang telah diuraiakan, maka simpulan dari penelitian ini adalah sebagai berikut:

Hasil penelitian menunjukkan hasil belajar pra siklus (40,74\%) pada siklus I meningkat menjadi $(74,07 \%)$ lalu meningkat lagi pada siklus II menjadi (92,59\%). Kemudian hasil penelitian siswa menunjukkan kemandirian belajar siswa pra siklus $(68,8 \%)$ pada siklus I meningkat menjadi $(76,94 \%)$ kemudian meningkat lagi pada siklus II (81,67\%). Dengan demikian penerapan Active Learning tipe Card Sort dapat meningkatkan kemandirian belajar dan hasil belajar IPS pada siswa kelas 5 SD Negeri Lopait 01.

Disarankan agar mengkaji lebih banyak referensi penelitian yang telah dilakukan sebelumnya sehingga dapat mengantisipasi kelemahan penggunaan model pembelajaran yang akan diterapkan pada penelitian mendatang agar lebih baik dan dapat menjadi referensi guru yang dapat diterapkan dalam kegiatan belajar mengajar.

\section{UCAPAN TERIMA KASIH}

Penulis mengucapkan terimakasih kepada Allah SWT karena berkat Rahmat, Hidayah serta Inayah-Nya penulis dapat menyeleseikan TA ini. Penulis berterimakasih pula kepada orang tua, adik dan keluarga tercinta yang tidak ada habisnya memberikan semangat. Serta kepada sahabat-sahabat dan orang-orang tercinta yang selalu menjadikan penyemangat di saat semangat mulai berkurang.

Terimakasih juga kepada pihak UKSW, FKIP UKSW, dan program studi Pendidikan Guru Sekolah Dasar. Baik para dosen dan teman-teman mahasiswa yang telah membantu penulis dalam kelancaran penyeleseian tugas akhir ini. Terimakasih yang sebesar-besarnya kepada kepala sekolah SD Negeri Lopait 01 Tuntang yang telah mengijinkan peneliti untuk melakukan penelitian di SD Negeri Lopait 01 Tuntang. Wali kelas 5 SD Negeri Lopait o1 Tuntang yang telah banyak membantu penulis dalam penelitian. Siswa kelas 5 SD Negeri Lopait 01 yang telah 
bersedia mengikuti segala langkah-langkah dalam penelitian ini.

Semoga Allah SWT memberikan balasan yang berlipat ganda kepada semuanya. Penelitian ini diharapkan dapat berguna bagi semua kalangan dan dapat memberikan inspirasi untuk melakukan penelitian selanjutnya.

\section{DAFTAR RUJUKAN}

[1] Anugraheni,I. (2017). Penggunaan Portofolio Dalam Perkuliahan Penilaian Pembelajaran. Jurnal Pendidikan Dasar Perkhasa, 3(1), 246-258.

[2] (2017). Analisa Faktor-Faktor yang Mempengaruhi Proses Belajar Guru-Guru Sekolah Dasar. Kelola: Jurnal Manajemen Pendidikan, 4(2), 205212.

[3] Anugraheni, I., Kristin, F., \& Airlanda, G. S. (2018). Pengembangan Bahan Ajar Pembelajaran Berasis Olah Pikir Di Sekolah Dasar. Inventa, 2(1), 33-39.

[4] Arikunto, dkk. 2008. Penelitian Tindakan Kelas. Jakarta: PT Bumi Aksara.

[5] Asep Jihad dan Abdul Haris. 2013. Evaluasi Pembelajaran. Yogyakarta: Multi Presindo.

[6] Baharun, H. (2015). Penerapan Pembelajaran Active Learning untuk Meningkatkan Hasil Belajar Siswa di Madrasah. Pedagogik: Jurnal Pendidikan, 1(1).

[7] Desminta. 2012. Psikologi Perkembangan Peserta Didik. Bandung: Remaja Rosdakarya.

[8] Hidayati, dkk. 2010. Pengembangan Pendidikan IPS SD. Direktorat Jenderal Pendidikan Tinggi Kementerian Pendidikan Nasional.

[9] Kristin, F., \& Rahayu, D. (2016). Pengaruh Penerapan Model Pembelajaran Discovery Learning Terhadap Hasil Belajar IPS Pada Siswa Kelas 4 SD. Scholaria: Jurnal Pendidikan dan Kebudayaan, 6(1), 84-92.

[10] Kristin, F. (2016). Efektivitas Model Pembelajaran Kooperatif Tipe Stad Ditinjau Dari Hasil Belajar Ips Siswa Kelas 4 SD. Scholaria: Jurnal Pendidikan dan Kebudayaan, 6(2), 74-79.

[11] (2017). Keberhasilan Belajar Mahasiswa Ditinjau Dari Keaktifan Dalam Perkuliahan Dengan Menggunakan Pembelajaran Active Learning. Jurnal Pendidikan Dasar PerKhasa, 3(2), 405-413.

[12] Kusumah, Wijayadan Dedi Dwitagama. 2010. Mengenal Penelitian Tindakan Kelas. Jakarta: PT Indeks.

[13] Mudjiman, Haris. 20011. Manajemen Pelatihan Berbasis Belajar Mandiri. Yogyakarta: Pustaka Pelajar.

[14] Rahmaningrum, M. (2016). Peningkatan Hasil Belajar IPS Melalui Strategi Pembelajaran Aktif Card Sort Siswa Kelas V. BASIC EDUCATION, 5(9), 913-921.

[15] Santosa, S. K. D. S. (2013). Penerapan Pembelajaran Aktif Student-Created Case Studies disertai Flip Chart untuk Meningkatkan Kemandirian Belajar Siswa dalam Pembelajaran Biologi Kelas XI IPA 4 SMA Negeri 4 Surakarta Tahun Ajaran 2009/2010. Bio-Pedagogi, 2(1), 88-98.

[16] Sapriya. 2012. Pendidikan IPS: Konsep dan Pembelajaran. Bandung: Remaja Rosdakarya

[17] Silberman, Mel. 2013. Pembelajaran Aktif. Jakarta: Indeks.

[18] Slameto. 2010. Belajar dan Faktor-faktor Yang Mempengaruhi. Jakarta: Rineka Cipta.
[19] 2015. Manajemen Berbasis Sekolah. Salatiga: Satya Wacana University Press.

[20]Sundayana, R. (2016). Kaitannya antara Gaya Belajar, Kemandirian Belajar, dan Kemampuan Pemecahan Masalah Siswa SMP dalam Pelajaran Matematika. Jurnal Pendidikan Matematika:STKIP Garut, 8(1), 31-40.

[21] Sugiono. 2013. Metode Penelitian Pendidikan. Bandung: Alfabeta.

[22] Susanto, Ahmad. 2013. Teori Belajar dan Pembelajaran di SD. Jakarta: Kencana Media Group.

\section{Biografi Penulis Utama}

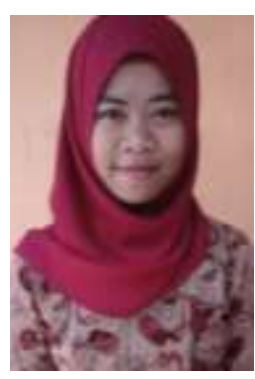

Penulis bernama lengkap Vera Risti Monika. Lahir di Semarang pada tanggal 21 Agustus 1995 dari pasangan Suparmo dan Rini Wuryandari. Penulis adalah anak pertama dari tiga bersaudara. Penulis menjalani pendidikan di SD N Susukan 01 tahun 2001-2003, di SD N Karangduren 04 pada tahun 2004-2006. Lalu melanjutkan ke SMP N 2 Tengaran pada tahun 20072010 dan SMA N 1 Tengaran pada tahun 2010-2013. Selanjutnya melanjutkan pendidikan di perguruan tinggi mengambil jurusan Pendidikan Guru Sekolah Dasar, Fakultas Keguruan dan Ilmu Pendidikan (FKIP) di Universitas Kristen Satya Wacana 2013-2018. Apabila terdapat kritik dan saran dapat dikirim melalui 292013144@student.uksw.edu. 